Original Research

\title{
Japanese Language Interest on Nursing Students toward Intention to Work in Japan at Stikes Pemkab Jombang
}

\section{Pepin Nahariani, Kikis Widya Ratna, Kolifah Kolifah, Iin Noviana and Shanti Rosmaharani}

Nursing Bachelor Department of STIKES Pemkab Jombang, Indonesia

\begin{abstract}
Introduction: In Indonesia, the working prevalence of nurses was that $95 \%$ worked in the country and 5\% were working abroad. The government provides opportunities for nurses who want to work in Japan through networking (Indonesia Japan Economic Partnership Agreement). However, there isn't a lot of interest due to the lack of knowledge of the Japanese language. This study aimed to analyze the Japanese language related to the nursing students' interest concerning working in Japan.
\end{abstract}

Methods: The design of the study was correlational research with a crosssectional approach which was conducted between May 31st and June 1st, 2016. The population consisted of nursing Bachelor's program students and the population totaled 41 ; the samples totaled as many as 37 . The data collection used Japanese observation test scores and questionnaires.

Results: The results showed that most of the $75.6 \%$ got a good score (B). Nearly half (48.6\%) of them were intending to work in Japan and $2.7 \%$ got great scores, also with the intent to work Japan. Based on the test results, the statistical value $=0.798$ that the $\rho$ value $>\alpha(0.05)$.

Conclusion: This means that there is no correlation between the Japanese language and the nurse's working interest related to Japan. The recommendation in this study is the implementation of an active Japanese language course. Further research should analyze the factors that affect the interests of Indonesian nurses when it comes to working in Japan.

\section{ARTICLE HISTORY}

Received: December 26, 2019

Accepted: December 31, 2019

\section{KEYWORDS}

japanese language; nursing students; intention

\section{CONTACT}

Pepin Nahariani

$₫$ pepin.nahariani@gmail.com

$\risingdotseq$ Nursing Bachelor Department of STIKES Pemkab Jombang, Indonesia

Cite this as: Nahariani, P., Ratna, K. W., Kolifah, K., Noviana, I. \& Rosmaharani, S. (2019). Japanese Language Interest on Nursing Students toward Intention to Work in Japan at Stikes Pemkab Jombang. Jurnal Ners, 14(3si), 247-251. doi:http://dx.doi.org/10.20473/in.v14i3(si).17123

\section{INTRODUCTION}

Every aspect of health service delivery requires nursing staff and other professional health personnel in order to produce competent and quality health services. Over the past 10 years, the international health workforce has increased for a variety of reasons (Santric-Milicevic et al., 2015). The shortage of nursing staff globally in developed countries has led to the active recruitment of nurses especially from developing countries, one of which is Indonesia (Efendi, Mackey, Huang, \& Chen, 2017). Indonesia has a lot of nursing workforce resources that it can use to supply the world's demands.

In reality however, there is a gap between the number of nursing staff and the distribution within the country. Indonesia is therefore experiencing a crisis of health access that should be sufficient for its own population. On the other hand, Indonesia has established cooperative relations with Japan in the Indonesia Japan Economic Partnership Agreement (IJEPA). In this cooperative agreement, the IJEPA has facilitated the migration of Indonesian nurses who want to work in Japan.

One of the facilities provided is Japanese language training, conducted for approximately 1 year. However, there is qualitative evidence that shows that some Indonesian nursing personnel have been returned because of their lack of Japanese language skills. Japanese is applied in the form of a Kangoshi / nursing exam that uses Japanese (Efendi et al., 2017). In Indonesia, the number of Diploma and Bachelor's of Nursing graduates in 2008 was 25,517. This then increased to 27,909 nurses in 2009. According to the data from the National Agency for Placement and Protection of Indonesian Workers (BNP2TKI), the 
demand for nurses to work abroad during 2010 2014 was for as many as 15,431 people. Only $36.5 \%$ of this demand was fulfilled. The latest data from the East Java Province shows that there are 55 Nursing Diploma Study Programs and 53 Bachelors of Nursing Study Programs producing around 12,000 nursing staff per year. This number will be of great potential for Indonesia when it comes to sending domestic nurses abroad to compete internationally (Efendi et al., 2013).

In Jombang, around as many as 845 out of 1,115 people work as nursing staff (Jombang Health Office, 2014). The crisis in the distribution of Indonesian nursing staff is known from the Health Office in 2014, which reported that 10,370 nurses were in public hospitals and that 4,213 were in community health centers throughout Indonesia. Out of the total number of nurses produced in 2014, an estimated $60 \%$ of them were utilized domestically, $5 \%$ were overseas and the rest worked outside of their competence (Efendi et al., 2017).

From the results of a preliminary study that was conducted on 10 undergraduate students in 4 th grade in semester VIII of Stikes Jombang who participated in the Japanese language course, it was found that $60 \%$ were interested in working in Japan with passive foreign language skills.

In the period of 2008 - 2011, the number of Indonesian nurses returning from Japan was many as 152 out of 363 nurses. The nurses returned to Indonesia for a variety of reasons. About 11 out of 20 nurses decided to return to Indonesia because they had completed the contract, 7 nurses returned for family reasons and the rest returned because they wanted to continue to pursue higher education. A report from the Ministry of Health shows that currently only a small number of prospective nursing staff are interested in returning to Japan via IJEPA. This is because they are worried about the long recruitment process and the risk of failing the nursing exam taken in the Japanese language (Efendi et al., 2013).

The use of nurses abroad is an alternative policy in order to optimize the use of nurses in relation to the principle of mutual benefit, both in terms of Indonesia and other countries that are partners, as well as between Indonesian nurses and those who use them. One use of nurses abroad is through the Indonesian Japan Economic Partnership Agreement (IJEPA). The IJEPA is part of the cooperation between Indonesia and Japan in reference to the placement of nurses and health workers that has been carried out since 2008 until now (Dinkes, 2017).

From the amount of available resources, Indonesia should be able to send nursing staff abroad. In reality however, there are many Indonesian nurses who are not interested in working abroad for various reasons. One important reason is their ability to speak a foreign language. Thus, hard work is needed to increase the utilization of nurses abroad while paying attention to their domestic needs.
Working abroad can be a personal desire or a cultural motive as an expression of choice, freedom and their human rights (HAM). It can also be the result of financial needs, job needs and challenges in order to face the nursing competition from others (Anna Kurniati E F, 2012).

To work abroad, one must be able to speak the relevant foreign language well, especially in accordance with the country that you want to go to as a place of work. In this case, the student's Japanese language skills must be truly mastered to facilitate communication while increasing the quality of the foreign workforce itself. Therefore IJEPA has provided Japanese language training for 6 months and also living in Japanese society for more than 1 year.

Jombang is a part of East Java that has many health workers. There are many health colleges in Jombang, such as the Faculty of Health Sciences in the University of Darul Ulum Jombang, Stikes Pemkab Jombang, Stikes Insan Cendekia Medika, Stikes Husada Jombang and Stikes Bahrul 'Ulum Jombang (Dinkes, 2017).

Thanks to several universities in Jombang, especially in the field of nursing, it opens up a great opportunity for prospective nursing staff in Jombang to work in Japan (Dinkes, 2017).

This study aims to determine the student's Japanese language ability and how much it affects the interest of the nursing Bachelor's students in Stikes Jombang Regency when it comes to working in Japan

\section{MATERIALS AND METHODS}

The design of study was analytical and correlational with a cross-sectional approach. The population was all of the students in 4th grade who followed the Japanese courses, totaling as many as 41 students. The sample was half of 4 th grade students of Stikes Pemkab Jombang who followed the Japanese courses, totaling as many as 37 students. The study used purposive sampling. The independent variable was foreign language ability (Japanese and Arabic) and the dependent variable was the interest in and intention to work in Japan. The instruments were an observation and a questionnaire that consisted of 12 questions from (Efendi et al., 2013).

The data collection technique started by the researcher submitting a research recommendation letter to the STIKES Pemkab Jombang institution. The data was from the 4th semester nursing undergraduate students of STIKES Pemkab Jombang. The prospective respondents of the study obeyed the rules that were given by the researcher. If they agreed to be a respondent, then they were welcomed to fill in the questionnaire. After all of the data had been obtained, the researcher analyzed the data. The analysis of the data used the Spearman Rank test $\alpha=$ 0.05 (Hidayat A A A, 2011). 


\section{RESULTS}

Table 1. Frequency Distribution based on Sex and Foreign Language $(\mathrm{n}=37)$

\begin{tabular}{lcl}
\hline & n & \% \\
\hline Sex & & \\
$\quad$ Male & 14 & 37.8 \\
$\quad$ Female & 23 & 62.2 \\
The interest of Foreign language & & \\
$\quad$ English & 13 & 35.2 \\
$\quad$ Japanese & 12 & 32.4 \\
$\quad$ Arabic & 12 & 32.4 \\
\hline
\end{tabular}

Table 2. Frequency Distribution based on foreign language ability

\begin{tabular}{ccc}
\hline $\begin{array}{c}\text { Foreign Language } \\
\text { ability }\end{array}$ & Scoring & Frequency (\%) \\
\hline A & $100-76$ & $1(2.7)$ \\
B & $75-66$ & $28(75.6)$ \\
C & $65-56$ & $8(21.7)$ \\
D & $55-46$ & $0(0)$ \\
E & $\leq 45$ & $0(0)$ \\
Total & & 37 \\
\hline
\end{tabular}

Table 3. Frequency Distribution based on the desire to work in Japan ( $\mathrm{n}=37)$

\begin{tabular}{lcc}
\hline $\begin{array}{l}\text { The interest of } \\
\text { work in Japan }\end{array}$ & $\mathbf{n}$ & $\mathbf{( \% )}$ \\
\hline High & 12 & 32.5 \\
Moderate & 25 & 67.5 \\
Low & 0 & 0.0 \\
\hline
\end{tabular}

Table 4. Cross-Tabulation of the Ability to Speak a Foreign Language with the Interest of the Nursing Students to Work in Japan

\begin{tabular}{|c|c|c|c|c|c|c|c|c|}
\hline \multirow{3}{*}{$\begin{array}{c}\text { Japa } \\
\text { nese } \\
\text { Lang } \\
\text { uage } \\
\text { Exam } \\
\text { Value }\end{array}$} & \multicolumn{6}{|c|}{ Interest in working in Japan } & \multicolumn{2}{|c|}{ Total } \\
\hline & \multicolumn{2}{|c|}{ High } & \multicolumn{2}{|c|}{$\begin{array}{c}\text { Moderat } \\
\text { e }\end{array}$} & \multicolumn{2}{|c|}{ Low } & \multirow[b]{2}{*}{$\Sigma$} & \multirow[b]{2}{*}{$\%$} \\
\hline & $\Sigma$ & $\%$ & $\Sigma$ & $\%$ & $\Sigma$ & $\%$ & & \\
\hline $\mathbf{A}$ & 0 & 0.0 & 1 & 2.7 & 0 & 0.0 & 1 & 100 \\
\hline B & $\begin{array}{l}1 \\
0\end{array}$ & 27 & 18 & 48.6 & 0 & 0.0 & 28 & 100 \\
\hline C & 2 & 5.4 & 6 & 16.2 & 0 & 0.0 & 8 & 100 \\
\hline D & 0 & 0.0 & 0 & 0.0 & 0 & 0.0 & 0 & 100 \\
\hline $\mathbf{E}$ & 0 & 0.0 & 0 & 0.0 & 0 & 0.0 & 0 & 0 \\
\hline
\end{tabular}

The results gained both common and specific data. The common data consisted of sex and the desire to learn a foreign language. The specific data consisted of the ability to learn a foreign language and the students' interest in working in Japan. The study was focused on the class taking the Japanese courses at STIKES Pemkab Jombang from May 31st to June 1st 2016.

\section{Common Data; Respondent Characteristics based on Sex and Interest in a Foreign Language}

Table 1. Based on the gender statistic, it showed that out of the nursing bachelor students in the 4th grade who followed the Japanese subject, there were as many as 23 female respondents (62,2\%). According to the interest in foreign language, the results showed that out of the nursing bachelor students, 35,2 \%, as many as 13 respondents, desired to learn English.

Specific Data; The characteristics of the respondent based on foreign language ability. Table 2 shows that the foreign language ability of the students on the nursing Bachelor's program in the 4 th grade who joined the Japanese courses, for as many as 28 respondents $(75,6 \%)$, was a $\mathrm{B}$.

The Characteristic of Respondent based on the interest to work in Japan

Table 3 shows that via the nursing Bachelor's program in the 4 th grade and regarding who joined the Japanese courses, as many as 25 respondent $(67,5 \%)$ had a moderate interest.

Cross-Tabulation of Ability to Speak a Foreign Language with the Interest of the Nursing Students to Work in Japan

The results showed that out of the 28 respondents who got a B, as many as 18 students, almost half the respondents (48.6\%), were moderately interested.

\section{DISCUSSION}

\section{Ability to speak foreign languages}

Table 2 showed that foreign language skills of 4 th level of nursing undergraduate students who take Japanese courses as many as 28 respondents, most of them $(75.6 \%)$ get $B$.

Language ability is the ability of an individual to hear the speech delivered by the interlocutor, such as when speaking with the other person, reading messages conveyed in written form and writing messages both verbally and non-verbally (Kepada, Ilmu, Dan, Untuk, \& Syarat, 2014).

The results of the study with the Japanese final examination score measuring instrument showed that the majority of respondents got a B in a good category. This is as the value was contained of reading, writing and speaking. In the questionnaire, there was a checklist of questions on foreign language skills (Japanese) related to their interest in working in Japan. From the results of the study, the average respondent had a moderate interest (questions number 1 to 4 ) which could be a benchmark of the extent of their foreign language skills. It can thus be concluded that their foreign language skills could be seen in the assessment of reading, writing and speaking in the final Japanese language test that has been carried out (Efendi et al., 2013).

\section{The interest to work in Japan}

Table 3 shows that the 4th Level nursing undergraduate students who participated in the Japanese language courses totaled 25 respondents, most of whom $(67.5 \%)$ had a moderate interest in working in Japan.

Interest is a source of motivation that encourages people to do what they want so then they are free to choose. If they see something that will be profitable, they feel interested. This brings in satisfaction. Their interest in the work will determine how much 
participation they put into a job. The stronger the interest and attention, the more concerned they are about the job.(Anna Kurniati E F, 2012)

The results of study via the interest questionnaire measurement showed that most of the respondents had a moderate interest in working in Japan. In the questionnaire, there was a checklist of questions about the interest in working in Japan based on age, level of education, marital status, family income, their source of information, the type of decision, kinship and experience abroad in order to try and find out what triggered their interest in working in Japan. From the results of the study, the average respondent had a moderate interest (questions number 5 to 12) which could be a benchmark for the extent of their interest in working in Japan. Thus, the interest in working in Japan can be influenced by the above factors (McKenna \& Brooks, 2018).

The correlation between Foreign Language Ability for 4th Level of Nursing Students of STIKES Pemkab Jombang with the Interest in Working in Japan

The results of study was conducted at the 4th level of the Nursing Program in STIKES Jombang and it found that there was no relationship between foreign language proficiency and the interest in working in Japan.

Table 4 shows that 28 respondents received a B, which is as many as 18 students. Almost half of the respondents (48.6\%) were moderate interested.

The Spearman Rank statistical test results obtained significant numbers or a probability value of 0.798 . This is higher than the significant standard 0.05 or $(r$ $>$ a). Thus, H0 was accepted and $\mathrm{H} 1$ was rejected, which means that there was no correlation between foreign language skills and the interest of the nursing undergraduate students in STIKES Pemkab Jombang to work in Japan.

The results of study that was conducted relating to the return of Indonesian nurses from Japan showed that 18 out of 20 skilled migrants were unemployed and looking for new jobs. Meanwhile, 2 returned to attend higher education. Evidence from the interviews revealed that it seemed to be very challenging for them to live in their home and they struggled with real life. They were looking for vacancies and they were looking for the best one that matched their qualifications. In this study, the participants returned for various reasons (Efendi et al., 2013).

11 of 20 nurses decided to emigrate back home because they had completed their contracts, 7 nurses returned for family reasons (hajj, planning to get married or to raise children, safety) and the rest were higher-level graduates.

The concept of the theory by Patricia Benner explained that nurses develop skills and an understanding of patient care from time to time through a combination of basic strong education and personal experience. Benner proposed that nurses could gain knowledge and skills without actually learning any of the theory involved. Language is not a theory, but a skill. In this study, the student respondents included in the advanced beginner stage were still in first place. However, there was no effect on language skills according to Imogene M. King's nursing theory, 'Human Being' which included perceptions, patient nurses and communication. This study focused on communication. Communication is the means of delivering information in the form of language. In this study, almost all of the respondents had good language skills but this did not affect their interest in working in Japan (Anna Kurniati E F, 2012).

The results of the study indicate that there is no correlation between foreign language skills and the interest in working in Japan. This is because the respondents in the Japanese classes were more interested in English than in Japanese and the highest score (A) in the exam was also very minimal. Almost all of the respondents got a $B$. There may be other factors such as family, experience and the information provided about the opportunity to work in Japan.

The family was the main reason for making the decision to work abroad for reasons of considerable distance. This could thus affect their interest in working in Japan. Experience was also important because work experience gained in the country could be different from Japan, which was seen of as more advanced technologically than Indonesia and thus they need more time to adjust through special training. The experience of going abroad could be a barrier for a few different reasons. Information about the opportunity to work in Japan in Indonesia had not been maximized, thus affecting the number of interested people.

\section{CONCLUSION}

The foreign language ability (Japanese) of the 4th level students in STIKES Pemkab Jombang who followed the Japanese language courses was increased, as most got $75.6 \%$, which is a B and in the good category. In the institution, for the 4 th Level of nursing undergraduate students who took Japanese courses, $67.5 \%$ were interested in working in Japan and they had a higher motivation to do the job in Japan. It has a good impact on the institution to reach an international vision. Based on the explanation above, there was no correlation between foreign language skills and the interest of 4th level nursing undergraduate students of STIKES Pemkab Jombang.

\section{REFERENCES}

Anna Kurniati E F. (2012). Kajian SDM Kesehatan di Indonesia. Jakarta: Medika Salemba.

Dinkes. (2017). Profil Kesehatan Kabupaten Jombang Tahun 2017. Dinas Kesehatan Kabupaten Jombang. Efendi, F., Mackey, T. K., Huang, M. C., \& Chen, C. M. (2017). IJEPA: Gray Area for Health Policy and International Nurse Migration. Nursing Ethics. https://doi.org/10.1177/0969733015602052 
Efendi, F., Purwaningsih, D., Qur'aniati, N., Kurniati, A., Singka, E. J., \& Chen, C.-M. (2013). Return migration of Indonesian nurses from Japan: Where should they go? Journal of Nursing Education and Practice. https://doi.org/10.5430/jnep.v3n8p154

Hidayat A A A. (2011). Metodelogi Penelitian Keperawatan dan Teknik Analisis Data. Jakarta: Medika Salemba.

Kepada, D., Ilmu, F., Dan, T., Untuk, K., \& Syarat, M. (2014). Pengaruh kemampuan berbahasa asing (arab-inggris) tehadap prestasi belajar siswa.
McKenna, L., \& Brooks, I. (2018). Graduate entry students' early perceptions of their future nursing careers. Nurse Education in Practice. https://doi.org/10.1016/j.nepr.2017.11.010

Santric-Milicevic, M., Matejic, B., Terzic-Supic, Z., Vasic, V., Babic, U., \& Vukovic, V. (2015). Determinants of intention to work abroad of college and specialist nursing graduates in Serbia. Nurse Education Today. https://doi.org/10.1016/j.nedt.2014.12.022 